\title{
Miniaturization in Otothyris Myers, 1927 (Loricariidae: Hypoptopomatinae)
}

\author{
Alaina Cristine Rosa, Fernanda de Oliveira Martins and Francisco Langeani
}

Many species of freshwater fishes are considered miniatures, nevertheless, their identification as miniatures is frequently based only on an arbitrary criterion of small body size. Although some species of Otothyris had been suggested to be miniature, informations about the process and consequences of miniaturization in the genus are lacking. Here, we detail developmental events of loss, fusion, and modifications in several bones, the laterosensory system, and even the brain, that in sum demonstrate miniaturization in all species of the genus. Our results may be useful in the recognition of other miniature species of loricariids.

Muitas espécies de peixes de água doce são consideradas miniaturas, entretanto, sua identificação é frequentemente baseada apenas no critério arbitrário que é seu reduzido tamanho corporal. Apesar de algumas espécies de Otothyris terem sido propostas como miniaturas, informações acerca do processo de miniaturização no gênero e suas consequências são escassas. Aqui detalhamos eventos de perda, fusão, modificações em muitos ossos, sistema laterossensorial e no cérebro, que juntos evidenciam a miniaturização em todas as espécies do gênero. Nossos resultados podem ser úteis na identificação de outras espécies miniaturas dentro de Loricariidae.

Key words: Freshwater, Heterochrony, Miniature, Neotropical region, Ontogeny.

\section{Introduction}

Miniaturization is a process that happened multiple times during vertebrate evolution. Although small body size is the trait most used to recognize the phenomenon, many other features can result from this evolutionary process. According to Hanken \& Wake (1993), many mechanisms and morphological consequences are involved in the decrease in body size, with these related to changes not only in the anatomy, but also in the physiology, ecology, life history, and behavior of the organism. Three different processes contribute to miniaturization: reduction and structural simplification, morphological novelty, and increased morphological variability (Hanken \& Wake, 1993). As a result, those authors consider the miniature phenotype as a complex combination of apparently ancestral and derived traits.

For South American freshwater fishes, Weitzman \& Vari (1988) considered miniature species to be those that did not exceed $26.0 \mathrm{~mm}$ in standard length (mm SL). Various features other than the reduced body size are additionally typical of miniature species. These include a reduction in the development of the laterosensory canals of the head and body, reductions in the number of fin rays and body scales, and a decrease of the sculpturing on the dermal bones of head (Weitzman \& Vari, 1988). All of those characteristics are related to the loss of terminal stages during the development of individual elements. Weitzman \& Vari (1988) listed 85 miniature freshwater fish species that were known in the Neotropical region, including species of the families Aspredinidae, Callichthyidae, Loricariidae, Pimelodidae, and Trichomycteridae in the Siluriformes. The only then known miniature species of loricariid catfish was Otothyris lophophanes (Eigenmann \& Eigenmann, 1889), the sole valid species of the genus at the time of Weitzman \& Vari's paper.

Otothyris is a member of the subfamily Hypoptopomatinae and is exclusive to coastal drainages. The genus is diagnosed by the presence of large fenestrae in the compound pterotic, salient crests of enlarged odontodes on the posterodorsal region of the supraoccipital and compound pterotic, and 12 branched caudal-fin rays (Garavello et al., 1998). At present, the genus is composed of four species, $O$. lophophanes, $O$. juquiae Garavello, Britski \& Schaefer, 1998, O. rostrata

UNESP, Universidade Estadual Paulista, Instituto de Biociências, Letras e Ciências Exatas, Departamento de Zoologia e Botânica, Laboratório de Ictiologia. Rua Cristóvão Colombo, 2265, 15054-000 São José do Rio Preto, SP, Brazil. ina_madden@hotmail.com (ACR); fernanda_martins2@hotmail.com(FOM); langeani@ibilce.unesp.br (FL) 
Garavello, Britski \& Schaefer, 1998, and O. travassosi Garavello, Britski \& Schaefer, 1998. All of these species share a reduced body size and the largest species, $O$. rostrata, reaches a maximum of $35.4 \mathrm{~mm}$ SL.

Following the suggestion by Weitzman \& Vari (1988) that $O$. lophophanes could be a miniature species, there was little discussion of the features related to the miniaturization process in this genus. In their taxonomic review of Otothyris, Garavello et al. (1998) observed the retention of juvenile traits in adults of $O$. lophophanes, O. juquiae, and O. rostrata, including the salient crests of enlarged odontodes on the supraoccipital and compound pterotic. A later study (Ribeiro et al., 2005) confirmed this observation and added the presence of a large naked area on the abdomen, the dome-like dorsal portion of the swimbladder capsule, and the presence of several prenasal plates as paedomorphic characters shared by Otothyris and Pseudotothyris Britski \& Garavello, 1984.

A recent study (Ribeiro et al., 2012) listed additional miniature loricariid species based only on body size. Although these authors also included $O$. lophophanes and $O$. rostrata in their list, they pointed out that these species exceeded the maximum body size proposed for miniature fish (i.e., $26.0 \mathrm{~mm} \mathrm{SL}$ ).

As mentioned by Weitzman \& Vari (1988), the definition of miniature species based solely on body size is arbitrary, and their list was presented as a preliminary guide for future studies of South America fishes. In this paper we present a morphological study including both sexes and several developmental stages of all known species of Otothyris. Our study provides new evidence of miniaturization in the genus, and highlights reductions that can be useful in identifying other miniature species within the Loricariidae.

\section{Material and Methods}

Specimens of the four species of Otothyris, including females and males, juveniles and adults (12.9-35.4 mm SL), preserved in $70^{\circ} \mathrm{GL}$ alcohol and cleared and stained (c\&s), following Taylor \& Van Dyke (1985), were examined. The central nervous system structures (CNS) were dissected and removed following Pupo (2011) as adapted to the Loricariidae. Sex determination was based on dimorphic secondary sexual characters in males (e.g., a dorsal skin flap on the pelvic-fin spine, a dilated nasal chamber, and a conspicuous papilla posterior of the genital pore). Osteological nomenclature followed Schaefer (1997) and brain nomenclature Northcutt (1980) and Nieuwenhuys (1982).

Institutional abbreviations are: DZSJRP, Coleção de Peixes do Departamento de Zoologia e Botânica, Instituto de Biociências, Letras, e Ciências Exatas, Universidade Estadual Paulista "Júlio de Mesquita Filho", São José do Rio Preto; MBML, Museu de Biologia "Prof. Mello Leitão",
Santa Teresa; MCN, Museu de Ciências Naturais, Fundação Zoobotânica do Rio Grande do Sul, Porto Alegre; MCP, Museu de Ciências e Tecnologia, Pontifícia Universidade Católica do Rio Grande do Sul, Porto Alegre; MHNCI, Museu de História Natural "Capão da Imbuia", Curitiba; MNRJ, Museu Nacional, Rio de Janeiro; MZUSP, Museu de Zoologia da Universidade de São Paulo, São Paulo; and UFRGS, Departamento de Zoologia, Universidade Federal do Rio Grande do Sul, Porto Alegre.

\section{Results}

Dermal plates. Otothyris has a loss and fusion of several plates of the head and body. The losses include the rostral plates, subocular plate, and plates of the lateral series.

Most loricariids have the anterior portion of the snout naked or with several small plates. This feature is shared by many basal members of the Hypoptopomatinae, such as Plesioptopoma Reis, Pereira \& Lehmann, 2012, Gymnotocinclus Carvalho, Lehmann \& Reis, 2008, and Rhinolekos Martins \& Langeani, 2011. The anterior region in other taxa in the Hypoptopomatinae is covered by one to four larger rostral plates. Four rostral plates are present in Pseudotothyris and Schizolecis Britski \& Garavello, 1984, which are closely related to Otothyris, that has only two plates. These two plates are equivalent in shape, size and position to the two more anterior plates in Pseudotothyris and Schizolecis (Fig. 1a). The loss of two rostral plates in Otothyris is the most parsimonious scenario according to Martins et al. (in press). Though varying between specimens and even contralaterally, the subocular plate may be also absent in Otothyris (Fig. 1c). Fused structures include the postrostral plates. Whereas most taxa in the Hypoptopomatinae have four postrostral plates, Pseudotothyris and Otothyris, as well as some members of the Hypoptopomatini, have only three plates. The second postrostral plate in these taxa has a similar size, shape and position as the sum of the second and third plates in the other members of the Hypoptopomatinae, which leads us to hypothesize the fusion of postrostral plates 2 and 3 (Fig. $1 \mathrm{~b}, \mathrm{c})$. According to Martins et al. (in press) these fusions in Pseudotothyris and Otothyris were independently acquired, when compared to those in some taxa in the Hypoptopomatini.

Basal lineages of the Hypoptopomatinae and related subfamilies have numerous and irregularly distributed prenasal plates; usually more than ten and reaching up to 50 in Plesioptopoma and Neoplecostomus microps (Steindachner, 1877), and 55 in Hypostomus careopinnatus Martins, Marinho, Langeani \& Serra, 2012. Otothyris has only three to seven pre-nasal plates. The seven small plates in $O$. rostrata occupy the space corresponding to the three to six larger plates in congeners. This pattern could be the result of many events of loss and/or fusion of plates. 

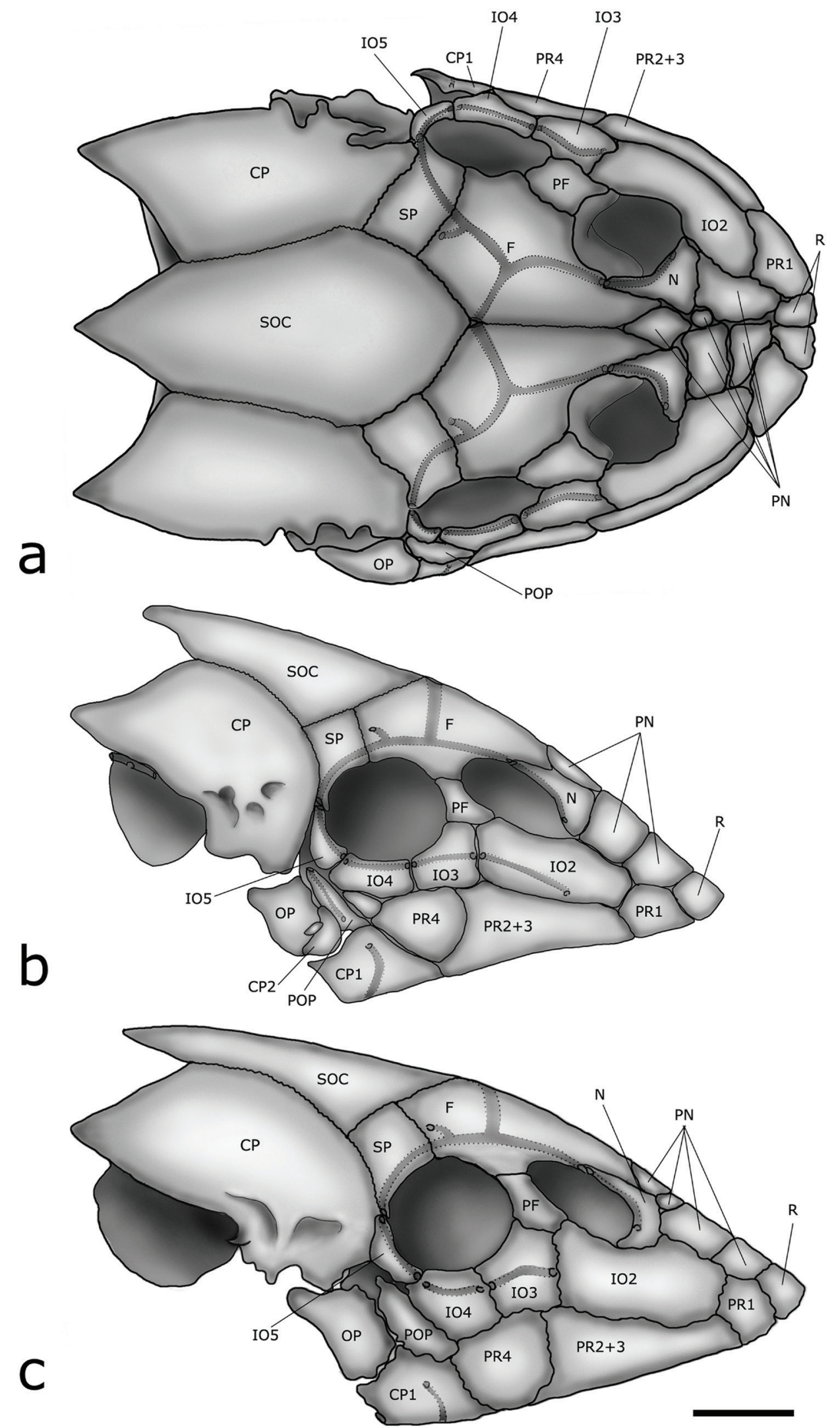

Fig. 1. Skull of Otothyris travassosi: a) MCP 36716, female, $27.5 \mathrm{~mm}$ SL (dorsal view). b) MCP 18100, female, $22.3 \mathrm{~mm}$ SL (right side). c) MCP 36716, female, $27.5 \mathrm{~mm}$ SL (right side). Abbreviations: CP, compound pterotic; CP1, canal-bearing plate 1; CP2, subocular cheek plate; F, frontal; IO2-5, infraorbitals 2-5; N, nasal; OP, opercle; PF, prefrontal plate; PN, pre-nasal plates; POP, preopercle; PR1-4, postrostral plates 1-4; R, rostral plate; SOC, supraoccipital; SP, sphenotic. Scale bar = $1 \mathrm{~mm}$. 
Fusion and loss events also involve the lateral body plates. Compared to other taxa in the Hypoptopomatinae, the mid-dorsal, median, and mid-ventral series of Otothyris are shorter (Fig. 2; fig. 3 in Schaefer, 1997). The mid-dorsal series has four to 13 plates; however, it never extends beyond the vertical through the end of the adpressed dorsal fin. The median series falls short of the end of the caudal peduncle, such that the posterior two or three plates of the dorsal and ventral series are in contact with each other. Furthermore, this series usually has plates missing posterior of the first perforated plates. The absence of mid-dorsal and mid-ventral series was suggested by Schaefer (2003) to represent a conservation of a juvenile feature in adults of Lithogenes Eigenmann, 1909, since these are the last series formed during ontogeny. The reduction of the number of plates in the mid-dorsal and mid-ventral series in Otothyris could be interpreted in the same way, and also related to the interruption of plate development.

Infraorbital series. The species of the Hypoptopomatinae usually have five infraorbital bones. Otothyris, however, has a reduced infraorbital series of only four infraorbitals (Fig. 1). This feature, also shared with Pseudotothyris, is a result of the loss of the infraorbital 1.
Laterosensory system. Otothyris has reductions in several portions of the laterosensory system, including the cephalic and lateral body canals.

While most taxa in the Hypoptopomatinae have the preopercle bearing a branch of the laterosensory system, the absence of this canal was reported in Acestridium Haseman, 1911, Otocinclus Cope, 1871, Oxyropsis Eigenmann \& Eigenmann, 1889, and Otothyris; the latter genus being reported as polymorphic for this feature (Schaefer, 1991, 1998). We observed the preopercular canal only in $O$. lophophanes and $O$. travassosi in the genus. However, these species are in fact polymorphic for this feature. This polymorphism is related to a loss of the canal during ontogeny, since it occurs only in juveniles smaller than $21.0 \mathrm{~mm} \mathrm{SL}$, whereas adults of all species of Otothyris lack the canal in the preopercle (Fig. 1b, c).

A reduction of the laterosensory canal system also occurs in the infraorbital series. Infraorbital 2 often lacks a laterosensory canal, mostly in adults (Fig. 1b, c).

Juveniles of approximately $15.0 \mathrm{~mm}$ SL have the median plate series of the body with canals extending from the compound pterotic to near to the base of the caudal fin (Fig. 2a), whereas this canal is reduced to different degrees depending on the species in adults (Fig. 2b, c). An associated

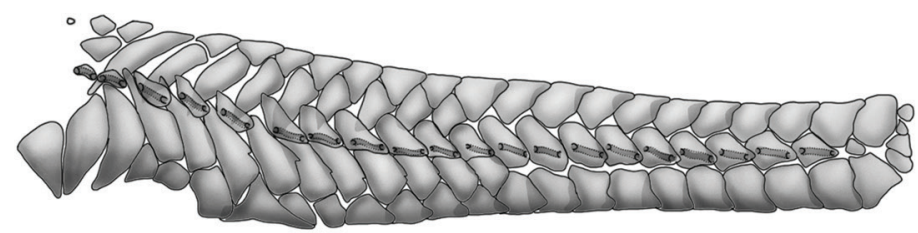

a

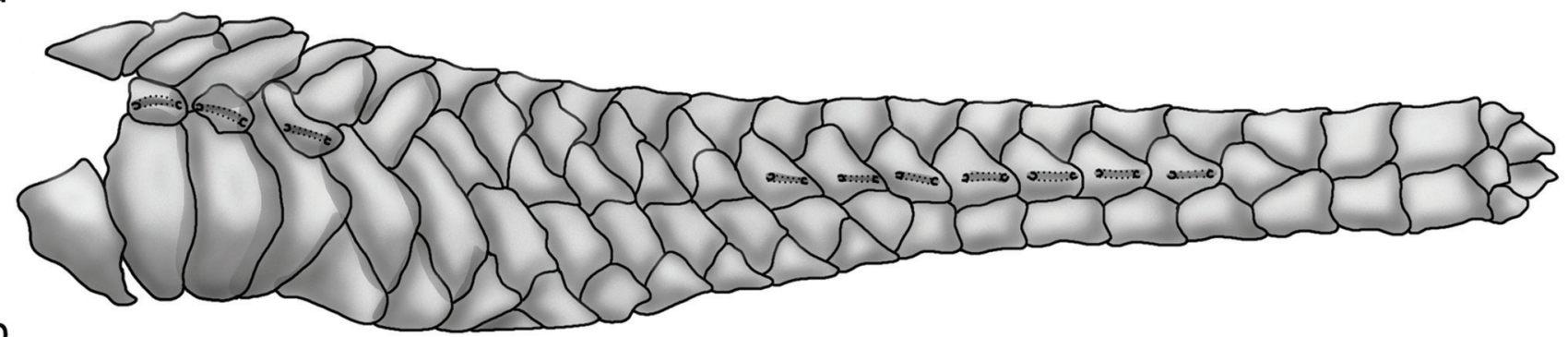

b

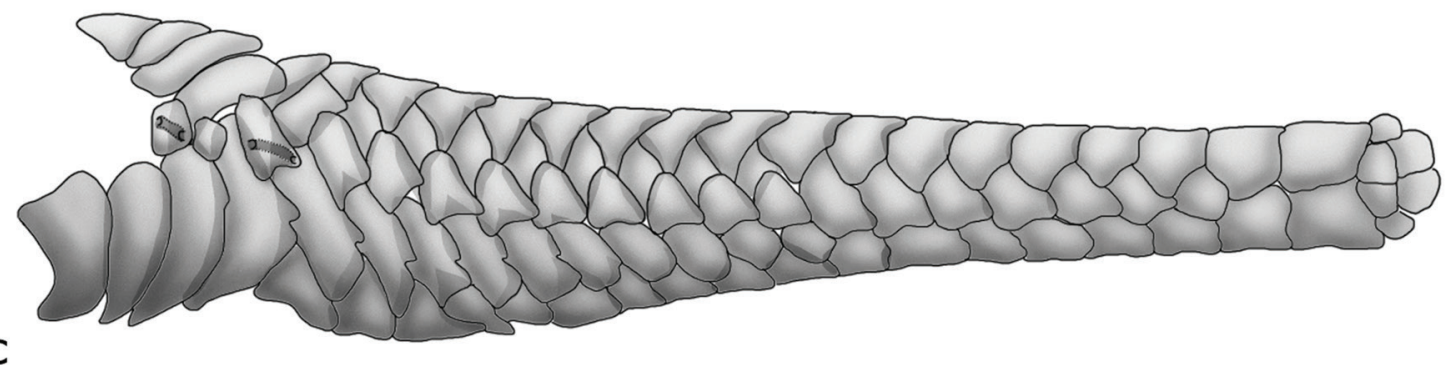

Fig. 2. Lateral plates of trunk (left side): a) Otothyris travassosi, MCP 418, undetermined sex, $15.5 \mathrm{~mm} \mathrm{SL}$. b) Otothyris travassosi, MCP 36716, female, $27.5 \mathrm{~mm}$ SL. c) Otothyris rostrata, MCN 18492, male, $23.6 \mathrm{~mm}$ SL. Scale bar = $1 \mathrm{~mm}$. 
loss of lateral-line canals occurs in the middle of the series, near the dorsal-fin base and on the last plates of the series. Thus, the pattern in most adults of Otothyris of the lateral line is of interspersed groups of plates bearing or lacking canal segments (Fig. 2b). This loss is most pronounced in $O$. rostrata in which only the anterior group of perforated plates remains (Fig. 2c).

In all of these cases, the laterosensory canals formed early in development are ontogenetically reabsorbed resulting in the loss of many canals in adults.

Vertebrae. Some of the basal genera in the Hypoptopomatinae, such as Plesioptopoma and Rhinolekos, have 31 or more vertebrae. This feature is shared with the Neoplecostominae, which is the sister to the Hypoptopomatinae. Conversely, a reduction to 25 to 28 vertebrae was observed in Otothyris.
Fins. Juveniles of several species of the Hypoptopomatinae have simple last, and less often, penultimate pectoral-, pelvic-, dorsal-, and anal-fin rays. Ramification of those rays occurs during ontogeny, resulting in a general pattern in the Loricariidae of a dorsal with seven, pectoral with six, and pelvic and anal fins with five branched rays. Most examined Otothyris specimens retain the last two rays unbranched in the pectoral and pelvic fins, and the last ray unbranched in the dorsal and anal fins, even in adults. A similar condition, of an unbranched terminal dorsal-, pectoral-, and pelvic-fin ray, was observed in Schizolecis and Pseudotothyris obtusa (Miranda Ribeiro, 1951), in Oxyropsis acutirostra Miranda Ribeiro, 1951 in which the last dorsal-, pectoral-, and anal-fin ray are unbranched, and in Pseudotothyris janeirensis Britski \& Garavello, 1984 and Otothyropsis marapoama Ribeiro, Carvalho \& Melo, 2005 in which only the last the pectoral-fin ray is unbranched.
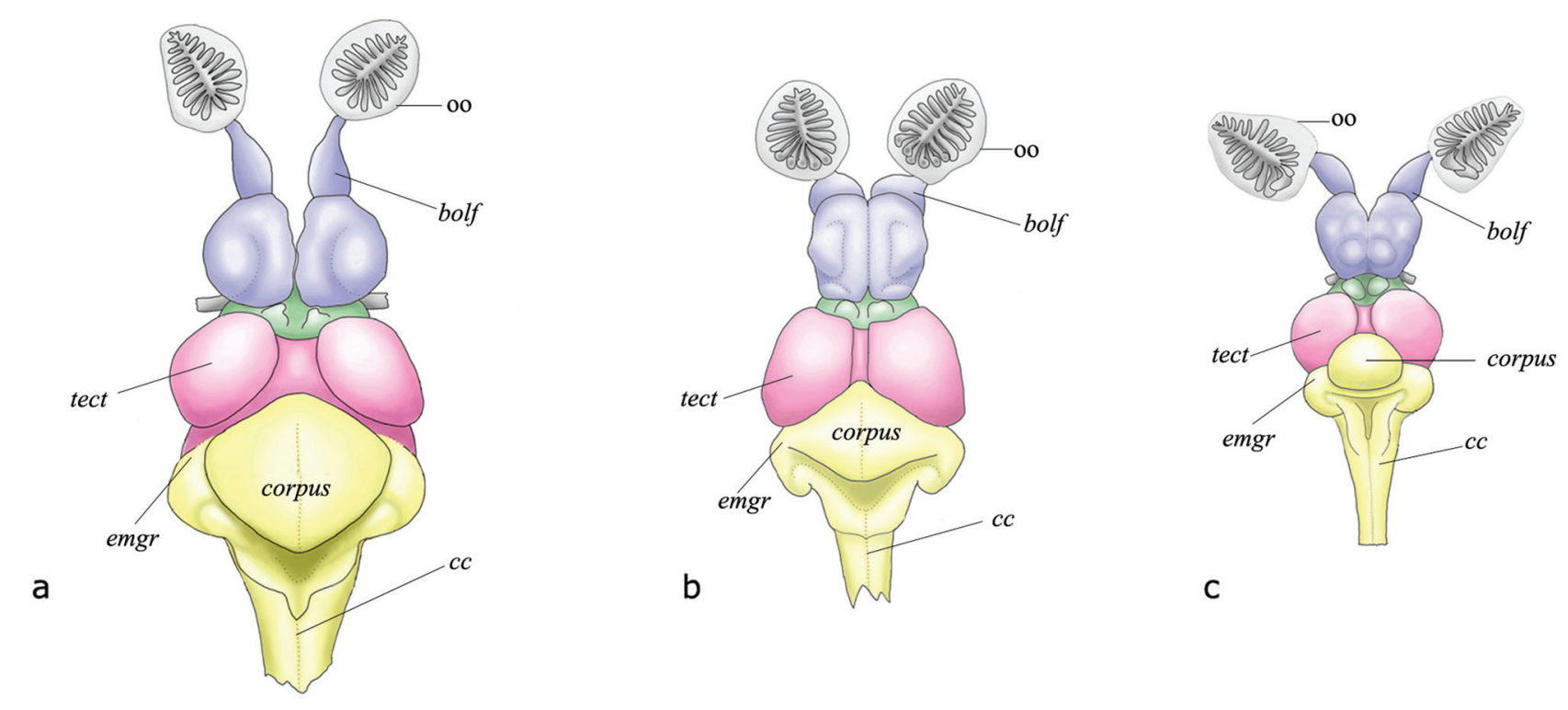

C

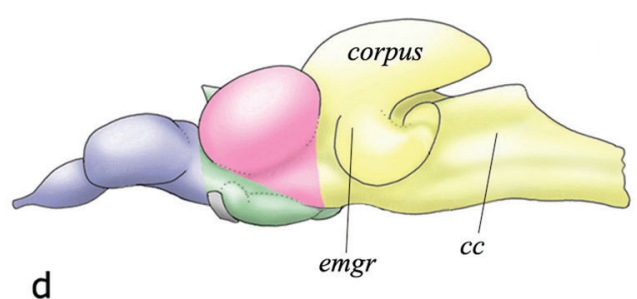

Telencephalon

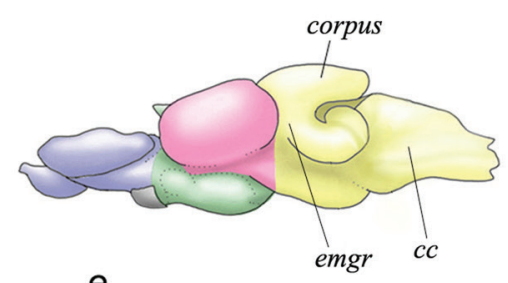

e

Diencephalon
Mesencephalon

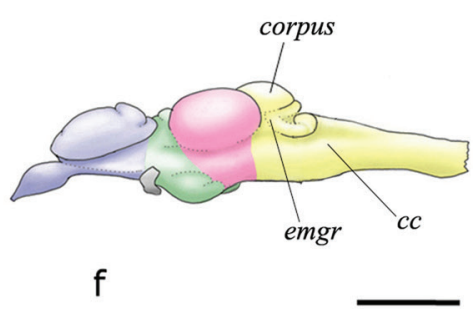

Rhombencephalon

Fig. 3. Brain in dorsal and left views: a, d) Gymnotocinclus anosteos, UFRGS 11296, female, $39.8 \mathrm{~mm}$ SL. b, e) Hisonotus notatus, DZSJRP 13852, female, 27.4 mm SL. c, f) Otothyris lophophanes, DZSJRP 13069, female, $26.3 \mathrm{~mm}$ SL. Abbreviations: bolf, bulbus olfactorius; cc, crista cerebellaris; corpus, corpus cerebelli; emgr, eminentia granularis; oo, olfactory organ; tect, tectum mesencephali. Scale bar $=1 \mathrm{~mm}$. Left view does not include olfactory organ. 
In juveniles of many hypoptopomatines, the inner portion of the pectoral-fin spine is ornamented with medial serrae, a feature completely lost during ontogeny. This was observed in Pseudotothyris, Schizolecis, some species of Hisonotus Eigenmann \& Eigenmann, 1889, Otothyropsis Ribeiro, Carvalho \& Melo, 2005, Otocinclus, and Parotocinclus Eigenmann \& Eigenmann, 1889. In some species within this subfamily, this feature is conserved to different degrees in adults. This feature was previously observed by Schaefer (1998) in Hypoptopoma Günther, 1868, Oxyropsis, Acestridium, and Niobichthys Schaefer \& Provenzano, 1998, and in this study for Otothyris, Pseudotothyris janeirensis, and Hisonotus chromodontus Britski \& Garavello, 2007.

Another modification of the fins in Otothyris is the reduction to 12 branched caudal-fin rays, whereas the remaining hypoptopomatines have 14 rays (except for Acestridium with 10 or 12 rays).

Brain. The brain of all craniates is composed of the telencephalon, diencephalon, mesencephalon, and rhombencephalon. Generally, the rostrodorsal portion of the rhombencephalon grows to form the cerebellum, by far the most variable part of the brain of actinopterygian fishes, both in size and shape (Nieuwenhuys, 1982). The cerebellum is posteriorly continuous with a distinct portion of the rhombencephalon, the crista cerebellaris. According to Lee \& Bullock (1984), the cerebellum likely acts as an integration center where sensory information from various inputs is processed and relayed to the motor centers.

The cerebellum of Otothyris is greatly reduced in size compared to that in Gymnotocinclus, a basal members of the Hypoptopomatinae and even Hisonotus, a more derived taxon of the subfamily (Fig. 3). This reduction is apparent mainly in the corpus cerebelli and eminentiae granularis. These are the portions of the cerebellum that mostly involve the somatosensory and mechanoreceptive functions, respectively. Moreover, the crista cerebellaris that is also related to the mechanoreceptive system, is similarly reduced. Thus, the reduction of these parts of the brain is probably related to the loss of many portions of the laterosensory system.

Morphological variability. An increase of morphological variability is usually associated with miniaturization (Hanken $\&$ Wake, 1993). Some variation in species of Otothyris could not be correlated with ontogeny or sexual dimorphism, occurring intrapopulationally or even contralaterally in the same individual. These features include: the arrangement of the abdominal plates, the presence of a subocular plate, the entry of the laterosensory canal into the infraorbital series via the sphenotic or compound pterotic, and the presence of the levator arcus palatini crest.

\section{Discussion}

Most of the features noted above can be associated with reduction and structural simplification, which as suggested by Hanken \& Wake (1993) is the first class of effects related to the miniaturization process. Furthermore, many of these losses are not linked to changes of development via ontogeny, but only with simplification arising from miniaturization. On the other hand, other features are clearly related to the interruption of development resulting in the retention of juvenile conditions in adults (i.e., heterochrony). These cases include the reduction of the mid-dorsal and mid-ventral lateral series of plates, the retention of simple rays in some fins and of the medial serrae on the pectoral-fin spine, the salient crests of enlarged odontodes on the supraoccipital and compound pterotic, and the dome-like dorsal portion of the swimbladder capsule. An interesting process related to miniaturization is the reduction and/or simplification via the resorption of structures formed earlier in the ontogeny (Hanken \& Wake, 1993), as observed in the laterosensory canals of the infraorbital series, preopercle, and lateral line in Otothyris. Initially, the resorption of bone structures could be thought of as unnecessary energy expenditure. Witten \& Villwock (1997), however, have shown that the growth of some skeletal elements requires its own resorption (e.g., the shaft of the preopercle and the scales of the lateral line including their sensory canals). Thus, it is possible that during the development in Otothyris the process has been interrupted leading to the absence of some portions of the laterosensory system.

Little is known about how a decrease in body size influences the morphology and size of the nervous system. Some studies analyzed the effects of such decrease in miniature salamanders and caecilians (Hanken, 1983; Roth et al., 1990; Roth et al., 1994; Roth et al., 1998; Schmidt \& Wake, 1997). To our knowledge the study herein is the first associating miniaturization effects with morphology of the brain morphology among Neotropical freshwater fishes. According to Haller's Rule, it is expected that the brain of smaller animals must be larger relative to their body size than are the brains of larger animals. This pattern is common for both vertebrates and invertebrates (Hanken, 1983; Quesada et al., 2011; Seid et al., 2011), and is related to a negative allometric growth between brain and body. Our results show that this pattern also occurs in loricariid catfishes, primarily when we consider the relative widths of the brain and head. In Hypostomus ancistroides (Ihering, 1911) and Rineloricaria latirostris (Boulenger, 1900), species that achieve greater body sizes compared to members of the Hypoptopomatinae, the head width corresponds approximately to seven and five times the brain width, respectively. In species of the Neoplecostominae and Hypoptopomatinae that only achieve comparatively 
smaller body sizes, such as Gymnotocinclus anosteos Carvalho, Lehmann \& Reis, 2008, Hisonotus notatus Eigenmann \& Eigenmann, 1889, Otothyris lophophanes, and Neoplecostomus microps, the head width is less than four times the brain width. Apparently, this shift is not directly related to miniaturization, but rather to a reduction in body size. Conversely, the reduction in some species of Otothyris in the volume of the main portion of the cerebellum associated with mechanoreception in the lateral line, can be interpreted as an effect of miniaturization.

Although some of the features discussed so far can also occur in isolation in other hypoptopomatines, Otothyris is the only genus having those all together. Thus, this seems to be a result of several events of loss and fusion in different systems that together result in a body size reduction and simplification. This illustrates the complexity of the miniaturization process in the genus. Some of these features are also shared with Pseudotothyris, the sister to Otothyris, suggesting that miniaturization may be widespread in the clade and must be interpreted as a gradual process, as already reported for cyprinids by Britz \& Conway (2009).

It is important in future studies to consider a wider variety of features other than body size that can be related to miniaturization. This could further the identification of miniature species of the Loricariidae and related families. Additionally, the interpretation of some character states in phylogenetic studies involving miniature fish should be made with care, since polymorphisms sometimes result from miniaturization.

Examined material. All from Brazil. Gymnotocinclus anosteos: UFRGS 11296, 6 of 20, 39.6-43.7 mm SL, 1 c\&s, 43.7 mm SL, 2 CNS, 39.8-42.8 mm SL, Goiás, Alto Paraíso de Goiás, rio dos Couros drainage. Hisonotus chromodontus: MZUSP 95942, 4, 19.3-21.8 mm SL, 1 c\&s, 19.3 mm SL, Mato Grosso, Itaúba, rio Tapajós drainage. Hisonotus notatus: all from Rio de Janeiro, Silva Jardim, rio São João drainage. DZSJRP 13852, 42, 14.4-41.1 mm SL, 2 c\&s, 14.3-17.7 mm SL, 2 CNS, 27.4-31.2 mm SL. MNRJ 13552, 30, 12.2-31.5 mm SL, 2 c\&s, 12.2-18.5 mm SL. MNRJ 38147, 10 of 42, 28.1-39.9 mm SL, $1 \mathrm{c} \& \mathrm{~s}, 31.0 \mathrm{~mm}$ SL. Hypostomus ancistroides: DZSJRP 17662, 108, 12.7-111.4 mm SL, 2 CNS, 98.9-101.9 mm SL, São Paulo, Jaboticabal, alto rio Paraná drainage, córrego Rico. Paratypes of Hypostomus careopinnatus Martins, Marinho, Langeani \& Serra 2012: DZSJRP 12447, 70, 21.2-57.0 mm SL, 2 c\&s, 50.3-52.4 mm SL, Mato Grosso, Alto Araguaia, rio Paraguay drainage. Neoplecostomus microps: DZSJRP 13908, 23, 30.9-81.6 mm SL, 2 CNS, 74.1-81.6 mm SL, São Paulo, Silveira-Cunha, rio Paraíba do Sul drainage. DZSJRP 18736, 3, 63.3-81.1 mm SL, 1c\&s, 63.3 mm SL, São Paulo, Cunha, rio Paraíba do Sul, stream on the Estrada Real Cunha-Parati. Paratypes of Otothyris juquiae Garavello, Britski \& Schaefer, 1998: MZUSP 51289, 14, 19.0-31.5 mm SL, 1 c\&s, 23.7 mm SL, São Paulo, Juquiá, rio Ribeira de Iguape drainage, Ponta da Volta pool. Otothyris lophophanes:
DZSJRP 13069, 49, 13.9-26.2 mm SL, 1 c\&s, 13.9 mm SL, 2 CNS, 18.0-26.3 mm SL, Rio de Janeiro, Macaé, rio Macaé drainage. MNRJ 22985, 20 of 64, 17.7-23.2 mm SL, 1 c\&s, 20.0 mm SL Espírito Santo, Cachoeiro do Itapemirim, rio Itapemirim drainage. Otothyris rostrata: MCN 18493, 16, 18.7-33.7 mm SL, 2 c\&s, 23.6-29.0 mm SL, Rio Grande do Sul, Torres, rio Tramandaí drainage. MHNCI 10322, 12, 17.4-30.6 mm SL, 1 c\&s, 29.1 mm SL, Santa Catarina, Araranguá, rio Sangrador drainage. Otothyris travassosi: MBML 418, 102, 15.5-32.8 mm SL, 3 c\&s, 15.5-28.7 mm SL, Espírito Santo, Santa Leopoldina, rio da Prata drainage. MBML 3248, 20 of 146, 12.9-27.1 mm SL, 2 c\&s, 12.9-27.1 mm SL, Conceição da Barra, córrego São Domingos. MBML 3336, 17, 14.2-29.5 mm SL, 1 c\&s, 29.5 mm SL, Anchieta, rio Benevente drainage. MCP 18099, 10 of 24, 19.6-26.1 mm SL, 2 c\&s, 21.2-26.1 mm SL, Helvécia, córrego Pau Alto. MCP 18100, 16, 16.0-23.9 mm SL, 2 c\&s, 21.2-22.3 mm SL, Monte Pascoal, rio Caraiva drainage. MCP 36716, 20 of 51, 16.7-28.2 mm SL, 3 c\&s, 22.1-27.5 mm SL, Alcobaça, rio Itatirentinga drainage. MNRJ 22947, 20 of 70, 16.7-25.6 mm SL, 3 c\&s, 20.9-25.4 mm SL, Itabatan, rio Mucurizinho drainage. MZUSP 39095, 10, 17.2-22.0 mm SL, 2 c\&s, 18.6-21.8 mm SL, Cumuruxatiba, rio do Sul drainage. MZUSP 94018, 10, 18.2-25.8 mm SL, 2 c\&s, 19.7-25.8 mm SL, Boundary between Minas Gerais and Bahia, road BR-418, unnamed stream. Paratypes of Otothyropsis marapoama Ribeiro, Carvalho \& Melo 2005: LIRP 5641, 4 of 48, 18.0-29.0 mm SL, 4 c\&s, 19.8-29.0 mm SL, São Paulo, Catanduva, rio Tietê drainage. Oxyropsis acutirostra: LBP 7193, 18 of 44, 23.5-32.7 mm SL, 2 c\&s, 28.4-29.3 mm SL, Amazonas, São Gabriel da Cachoeira, rio Negro drainage. Parotocinclus maculicauda: DZSJRP 3137, 2, 35.7-41.5 mm SL, 1 c\&s, 35.7 mm SL, São Paulo, Jacupiranga, rio Jacupiranga drainage. Plesioptopoma cuvidens: DZSJRP 16133, 69, 13.4-91.5 mm SL, 2 c\&s, 30.1-51.4 mm SL, Minas Gerais, Cristiano Otoni, rio São Francisco drainage. Paratypes of Pseudotothyris janeirensis Britski \& Garavello, 1984: MNRJ 4707, 21 of 114, 16.8-35.3 mm SL, 1 c\&s, 40.0 mm SL, Rio de Janeiro, Paulo de Frontin, rio dos Macacos drainage. Pseudotothyris obtusa: MCP 31726, 7, 21.2-28.3 mm SL, 1 c\&s, 24.2 mm SL, São Paulo, Mongaguá, unnamed stream. MZUSP 69411, 8, 23.1-28.5 mm SL, 1 c\&s, 23.1 mm SL, Juquiá, Ribeira de Iguape drainage. Rhineloricaria latirostris: DZSJRP 17682, 6, 62.1-118,6 mm SL, 1 CNS, 107.4 mm SL, São Paulo, Jaboticabal, alto rio Paraná drainage, córrego rico. Paratypes of Rhinolekos britskii Martins, Langeani \& Costa 2011: DZSJRP 6983, 7, 16.8-40.0 mm SL, 1 c\&s, 36.0 mm SL, Goiás, Bela Vista de Goiás, rio Paranaíba drainage. DZSJRP 12190, 17, 21.8-35.5 mm SL, 1 c\&s, $28.0 \mathrm{~mm}$ SL, Bela Vista de Goiás, rio Paranaíba drainage. Schizolecis guntheri: DZSJRP 6525, 25, 21.7-34.4 mm SL, 1 c\&s, 32.9 mm SL, São Paulo, Bertioga, unnamed stream.

\section{Acknowledgments}

We are grateful to Carlos A. Lucena (MCP), Luisa M. Sarmento-Soares (MBML), Luiz R. Malabarba (UFRGS), Marcelo R. Britto and Paulo A. Buckup (MNRJ), Marco Aurélio Azevedo (MCN), Osvaldo T. Oyakawa (MZUSP), 
Vinicius Abilhoa (MHNCI) for the loan of specimens. The authors were supported by fellowships from the Fundação de Amparo à Pesquisa do Estado de São Paulo (FAPESP, 2012/04274-5 to ACR, 2011/21728-7 to FOM), Conselho Nacional de Desenvolvimento Científico e Tecnológico (CNPq, 305946/2011-0 to FL), and Coordenação de Aperfeiçoamento de Pessoal de Nível Superior (CAPES) to ACR.

\section{Literature Cited}

Britz, R. \& K. W. Conway. 2009. Osteology of Paedocypris, a miniature and highly developmentally truncated fish (Teleostei: Ostariophysi: Cyprinidae). Journal of Morphology, 270: 389-412.

Garavello, J. C., H. A. Britski \& S. A. Schaefer. 1998. Systematics of the genus Otothyris Myers 1927, with comments on geographic distribution (Siluriformes: Loricariidae: Hypoptopomatinae). American Museum Novitates, 3222: 1-19.

Hanken, J. 1983. Miniaturization and its effects on cranial morphology in Plethodontid salamanders, genus Thorius (Amphibia, Plethodontidae): II. The fate of the brain and sense organs and their role in skull morphogenesis and evolution. Journal of Morphology, 177: 255-268.

Hanken, J. \& D. B. Wake. 1993. Miniaturization of body size: organismal consequences and evolutionary significance. Annual Review of Ecology and Systematics, 24: 501-519.

Lee, L. T. \& T. H. Bullock. 1984. Sensory representation in the cerebellum of the catfish. Neuroscience, 13: 157-169.

Martins, F. O., H. A. Britski \& F. Langeani. (in press). Systematics of Pseudotothyris (Loricariidae: Hypoptopomatinae). Zoological Journal of the Linnean Society.

Nieuwenhuys, R. 1982. An overview of the organization of the brain of actinopterygian fishes. American Zoologist, 22: 287-310.

Northcutt, R. G. 1980. Central auditory pathways in anamniotic vertebrates. Pp: 79-118. In: A. N. Popper \& R. R. Fay (Eds.). Comparative studies of hearing in vertebrates. New York, Springer-Verlag.

Pupo, F. M. R. S. 2011. Anatomia comparada da morfologia externa do sistema nervoso central da família Callichthyidae (Teleostei: Ostariophysi: Siluriformes) e suas implicações filogenéticas. Unpublished M.Sc. Dissertation, Universidade Federal do Rio de Janeiro/Museu Nacional, Rio de Janeiro, 97p.

Quesada, R., E. Triana, G. Vargas, J. K. Douglass, M. A. Seid, J. E. Niven, W. G. Eberhard \& W. T. Wcislo. 2011. The allometry of CNS size and consequences of miniaturization on orb-weaving and cleptoparasitic spiders. Arthropod Structure \& Development, 40: 521-529.

Ribeiro, A. C., M. Carvalho \& A. L. A. Melo. 2005. Description and relationship of Otothyropsis marapoama, a new genus and species of Hypoptopomatinae catfish (Siluriformes: Loricariidae) from rio Tietê basin, southeastern Brazil. Neotropical Ichthyology, 3: 489-498.
Ribeiro, A. C., F. T. C. Lima \& E. H. L. Pereira. 2012. A new genus and species of a minute suckermouth armored catfish (Siluriformes: Loricariidae) from the rio Tocantins drainage, central Brazil: the smallest known loricariid catfish. Copeia, 2012: 637-647.

Roth, G., J. Blanke \& D. B. Wakeo. 1994. Cell size predicts morphological complexity in the brains of frogs and salamanders. Proceedings of the National Academy Sciences, 91: 4796-4800.

Roth, G., B. Rottluff, W. Grunwald, J. Hanken \& R. Linke. 1990. Miniaturization in plethodontid salamanders (Caudata: Plethodontidae) and its consequences for the brain and visual system. Biological Journal of the Linnean Society, 40: 165-190.

Roth, G., B. Rottluff \& R. Linke. 1998. Miniaturization, genome size and the origin of functional constraints in the visual system of salamanders. Naturwissenschaften, 75: 297-304.

Schaefer, S. A. 1991. Phylogenetic analysis of the loricariid subfamily Hypoptopomatinae (Pisces: Siluroidei: Loricariidae), with comments on generic diagnoses and geographic distribution. Zoological Journal of the Linnean Society, 102: 1-41.

Schaefer, S. A. 1997. The Neotropical cascudinhos: systematics and biogeography of the Otocinclus catfishes (Siluriformes: Loricariidae). Proceedings of the Academy of Natural Sciences of Philadelphia, 148: 1-120.

Schaefer, S. A. 1998. Conflict and resolution: impact of new taxa on phylogenetic studies of the Neotropical cascudinhos (Siluroidei: Loricariidae). Pp. 375-400 .In: Malabarba, L. R., R. E. Reis, R. P. Vari, Z. M. S Lucena \& C. A. S. Lucena (Eds.). Phylogeny and classification of Neotropical fishes. Porto Alegre, Edipucrs.

Schaefer, S. A. 2003. Relationships of Lithogenes villosus (Siluriformes, Loricariidae): evidence from high-resolution computed microtomography. American Museum Novitates, 3401: 1-55.

Schmidt, A. \& M. H. Wake. 1997. Cellular migration and morphological complexity in the caecilian brain. Journal of Morphology, 231: 11-28.

Seid, M. A., A. Castillo \& W. T. Wcislo. 2011. The allometry of brain miniaturization in ants. Brain Behavior and Evolution, 77: 5-13.

Taylor, W. R. \& G. C. Van Dyke. 1985. Revised procedures for staining and clearing small fishes and other vertebrates for bone and cartilage study. Cybium, 9: 107-119.

Weitzman, S. H. \& R. P. Vari. 1988. Miniaturization in south american freshwater fishes; An overview and discussion. Proceedings of the Biological Society of Washington, 101: 444-465.

Witten, P. E. \& W. Villwock. 1997. Growth requires bone resorption at particular skeletal elements in a teleost fish with acellular bone (Oreochromis niloticus, Teleostei: Cichlidae). Journal of Applied Ichthyology, 13: 149-158.

Submitted August 20, 2013

Accepted December 2, 2013 by George Mattox

Published March 31, 2014 